\title{
Analisis Efisiensi Teknis Industri Perabot di Kecamatan Jeumpa Kabupaten Bireuen dengan Data Envelopment Analysis (DEA) Method
}

\author{
Devi Andriyani ${ }^{1}$, Munandar ${ }^{2}$, Fuadi ${ }^{3}$ \\ 1,2,3 Fakultas Ekonomi dan Bisnis Universitas Malikussaleh, Kota \\ Lhokseumawe, Indonesia.
}

\begin{abstract}
Abstrak. Penelitian ini bertujuan untuk mengetahui efisiensi teknis pemakaian input (nilai investasi, nilai bahan baku dan biaya tenaga kerja) terhadap output (nilai produksi) dari industri perabot di kecamatan Jeumpa Kabupaten Bireuen. Sampel yang digunakan sebanyak 53 unit industri yang merupakan keseluruban unit industry perabot di Kecamatan Jeumpa Kabupaten Bireuen. Adapun metode analisis data menggunakan alat analisis Data Envelopment Analisis (DEA) dengan pendekatan VRS. Hasil penelitian diperoleh banya 30 unit industri perabot di Kecamatan Jeumpa yang telah efisien dalam penggunaan input sedangkan 23 unit industri lainnya belum mampu mencapai efisiensi pemakaian input.
\end{abstract}

Kata kunci: nilai produksi, biaya investasi, biaya bahan baku, biaya tenaga kerja, DE $A$.

Abstract. This study aims to determine the technical efficiency of input use (investment value, raw material value and labor cost) on the output (production value) of the furniture industry in Jeumpa sub-district, Birenen Regency. The sample used is 53 industrial units which are all furniture industry units in Jeumpa District, Bireuen Regency. The data analysis method uses the Data Envelopment Analysis (DEA) analysis tool with the VRS approach. The results showed that only 30 units of furniture industry in Jeumpa District were efficient in using input, while 23 other industrial units had not been able to achieve efficiency in input use.

Keywords: production value, investment costs, raw material costs, labor costs, DE $A$. 


\section{Pendahuluan}

Industri perabot merupakan salah satu industri yang mampu tetap bertahan dalam berbagai kondisi ekonomi dan terus memiliki peminatnya sendiri. Peningkatan kebutuhan akan tempat tinggal, perkembangan usaha oleh swasta dan pembangunan sarana prasarana umum, akan menjadi faktor penunjang utama peningkatan permintaan perabot. Kabupaten Bireuen merupakan salah satu daerah yang mengandalkan sektor industri, dalam pembangunan dan pengembangan daerahnya. Kabupaten Bireuen juga menjadikan industri perabot sebagai industri andalan.

Industri Furniture dari kayu yang lebih dikenal dengan nama industri perabot di Kabupaten Bireuen tersebar di hampir semua kecamatan di Kabupaten Bireuen. Data persebaran unit usaha perabot di Kabupaten Bireuen dapat dilihat pada gambar 1 berikut.

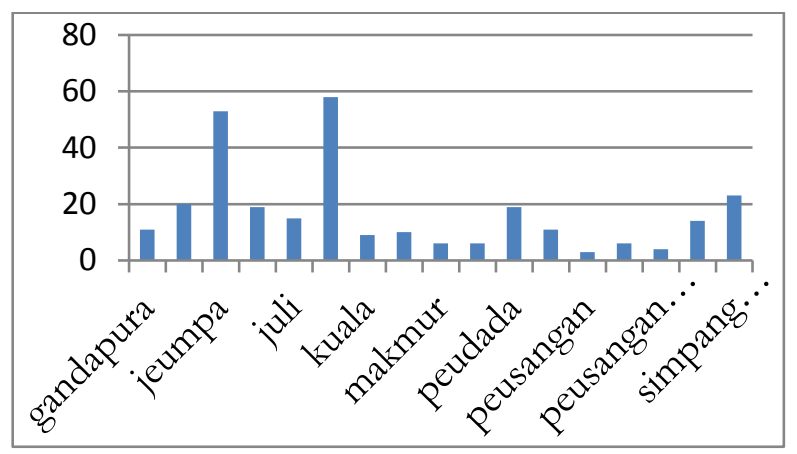

Sumber data dinas perindustrian kabupaten Bireuen (2019)

Gambar 1. Jumlah unit usaha industri perabot setiap kecamatan di Kabupaten Bireuen

Berdasarkan gambar 1 dapat diketahui bahwa pada tahun 2019 unit usaha industri perabot paling banyak di kecamatan kota juang yaitu terdapat 58 unit usaha, selanjutnya diikuti oleh kecamatan Jeumpa sebanyak 53 unit usaha dan pada urutan ketiga terdapat di Kecamatan Simpang Mamplam sebanyak 23 unit usaha.

Walaupun di Kecamatan Kota Juang paling banyak terdapat usaha perabot tetapi berdasarkan data dari dinas perindustrian Kabupaten Bireuen selama 3 tahun terakhir usaha ini stabil dan tetap jumlah unit usahanya di Kecamatan Jeumpa, Ini menunjukkan usaha ini dapat bertahan di Kecamatan Jeumpa. Sedangkan di kecamatan Kota Juang penambahan jumlah unit usaha menjadi 58 unit usaha baru terjadi pada tahun 2019 dimana tahun sebelumnya hanya 51 unit usaha. Kestabilan keberadaan jumlah unit usaha di suatu daerah mencerminkan bahwa usaha tersebut mampu menghasilkan nilai produksi yang tinggi bagi pengusahanya.

Pada industri perabot nilai dari output produksi sangat dipengaruhi oleh kualitas output produksinya. Jenis bahan baku, Kerapian, keunikan dan model ukiran yang dipakai sangat menentukan nilai outputnya. Sehingga terkadang satu output yang dihasilkan oleh satu unit usaha industri sama dengan 10 output yang dihasilkan oleh unit usaha lain nya karnanya diperlukan kombinasi penggunaan input yang tepat dan efisien untuk menghasilkan output produksi bernilai tinggi dan dapat menambah pendapatan pengusaha.

Ada beberapa faktor yang menyebabkan flutuasi pendapatan industri perabot. Faktor utamanya adalah nilai investasi atau modal kerja. Bilas (2018) menyatakan nilai investasi sangat berpengaruh terhadap berjalannya operasi suatu perusahaan. Berdasarkan pengamatan, permasalahan terbesar yang dihadapi oleh industri perabot di Kabupaten Bireuen adalah kurangnya investasi pada modal kerja, pelaku usaha industri perabot memiliki keterbatasan modal kerja, karena itu mereka umumnya memproduksi barang setelah ada pesanan, hal ini menyebabkan konsumen harus menunggu untuk memperoleh pesanan mereka, inilah yang menyebabkan konsumen lebih memilih membeli perabotan siap jadi yang berasal dari luar daerah.

Faktor kedua yang memiliki peranan penting dalam industri perabot adalah pemakaian tenaga kerja. Pada industri perabotan, kerapian, kreatifitas dan ide-ide baru menentukan harga hasil produksi. Permasalahan yang dihadapi adalah kurang tersedianya tenaga kerja yang handal dan terampil dibidang furniture dari penduduk lokal, sehingga menyebabkan output yang dihasilkan kurang menarik. Dan akhirnya pengusaha perabot biasanya harus mendatangkan tenaga kerja dari luar daerah yang menyebabkan biaya tenaga kerja meningkat. Selain biaya modal dan tenaga kerja, permasalahan lainnya adalah ketersediaan bahan baku dan harga bahan baku. 
Bahan baku usaha perabot yang umumnya berupa kayu sangat sulit didapatkan karna kayu yang bagus adalah kayu yang berasal dari tanaman keras yang telah berumur lebih dari 10 tahun dan tanaman ini termasuk salah satu sumberdaya alam yang berperan tinggi dalam menjaga stabilitas alam dan memiliki fungsi biologis yang sangat penting, sehingga eksistensinya dilindungi dan dikarenakan sulit didapatkan maka harganya juga relatif mahal. Belum lagi jika tenaga kerja yang dipakai tidak mampu mengefisienkan pemakaian tentu akan menimbulkan kerugian.

Berdasarkan Permasalahan yang telah dipaparkan diatas maka perlu dilakukan penelitian terhadap efektifitas pemakaian biaya input terhadap output dari unit-unit usaha industri perabot yang ada di Kecamatan Jeumpa Kabupaten Bireuen dengan menggunakan metode yang sederhana dan nantinya dapat direkomendasikan untuk membantu para pelaku usaha perabot.

\section{Literature Review}

\section{Efisiensi Teknis}

Menurut Kumbakhar dan Lovell (2010), produsen dikatakan efisien secara teknis jika dan hanya jika tidak mungkin lagi memproduksi lebih banyak output dari yang telah ada tanpa mengurangi sejumlah output lainnya atau dengan sejumlah input tertentu. Menurut Bakhshoodeh dan Thomson (2011), produsen yang efisien secara teknis adalah produsen yang dapat menghasilkan output yang lebih besar dari produsen lainnya dengan menggunakan sejumlah input tertentu. Bakhsh et al. (2016) menyatakan bahwa terdapat tiga kemungkinan cara untuk meningkatkan produksi, yaitu dengan menambah bahan baku, mengembangkan dan mengadopsi teknologi baru, dan menggunakan sumberdaya yang tersedia secara lebih efisien (efisiensi teknis).

\section{Pengukuran Efisiensi}

Pengukuran efisiensi dapat dilakukan melalui tiga pendekatan yaitu

1. Pendekatan rasio

Pendekatan rasio dalam mengukur efisiensi dilakukan dengan menghitung perbandingan output dengan input yang digunakan. Pendekatan rasio akan dinilai memiliki efisiensi yang tinggi apabila dapat memproduksi jumlah ouput maksimal dengan jumlah input seminimal mungkin. Kelemahan dari pendekatan ini adalah bila terdapat banyak input dan banyak output yang akan dihitung, karena apabila dilakukan perhitungan secara serempak akan menimbulkan banyak hasil perhitungan sehingga menghasilkan asumsi yang tidak tegas (Ario, 2015).

2. Pendekatan regresi

Pendekatan ini dalam mengukur efisiensi menggunakan sebuah model dari tingkat output tertentu sebagai fungsi dari berbagai tingkat input tertentu. Pendekatan regresi akan menghasilkan estimasi hubungan yang dapat digunakan untuk memproduksi tingkat output yang dihasilkan sebuah Unit Kegiatan Ekonomi (UKE) pada tingkat input tertentu. UKE tersebut akan dinilai efisien bila mampu menghasilkan jumlah output lebih banyak dibandingkan jumlah output hasil estimasi. Pendekatan ini juga tidak dapat mengatasi kondisi banyak output, karena hanya satu indikator output yang dapat ditampung dalam sebuah persamaan regresi (Ario, 2015).

3. Pendekatan frontier

Menurut Ario (2015), pendekatan frontier dalam mengukur efisiensi dibedakan menjadi dua jenis, yaitu pendekatan frontier parametik dan non parametik. Pendekatan frontier parametik dapat diukur dengan tes statistik parametik seperti menggunakan metode Stochastic Frontier Approach (SFA) dan Distribution Free Approach (DFA). Pendekatan frontier non parametik diukur dengan tes statistik non parametik yaitu dengan menggunakan metode Data Envelopment Analysis (DEA).

\section{Pendekatan Non Parametik Metode DEA}

Data Envelopment Analysis (DEA)

Dalam penelitian ini untuk mengukur efisiensi pemakaian biaya-biaya produksi terhadap pendapatan usaha dengan menggunakan Data Envelopment Analysis (DEA). Analisis Data Envelopment data (DEA) adalah metode nonparametrik dalam penelitian operasi dan ekonomi untuk memperkirakan batas produksi. Hal ini digunakan untuk secara empiris 
mengukur efisiensi produksi unit pembuat keputusan atau Decision Making Unit (DMU). Meskipun DEA memiliki kaitan yang kuat dengan teori produksi di bidang ekonomi, alat ini juga digunakan untuk pembandingan dalam manajemen operasi, di mana satu set tindakan dipilih untuk membandingkan kinerja operasi manufaktur dan layanan. Dalam keadaan benchmarking, DMU yang efisien, seperti yang didefinisikan oleh DEA, mungkin tidak harus membentuk "production frontier", namun mengarah pada "best-practice corner". Terdapat dua faktor yang mempengaruhi dalam pemilihan DMU, yaitu : DMU harus merupakan unit-unit yang homogen. Unit-unit tersebut melakukan tugas (task) yang sama, dan memiliki obyektif yang sama. Input dan output yang mencirikan kinerja dari DMU harus identik, kecuali berbeda hanya intensitas dan jumlah/ukurannya (magnitude).Ada tiga manfaat yang diperoleh dari pengukuran efisiensi dengan DEA, diantaranya: 1. sebagai tolak ukur untuk memperoleh efisiensi relatif yang berguna untuk mempermudah perbandingan antar unit ekonomi yang sama.

2. mengukur berbagai variasi efisiensi antar unit ekonomi untuk mengidentifikasi faktorfaktor penyebabnya.

3. menentukan implikasi kebijakan sehingga dapat meningkatkan tingkat efisiensinya.

\section{Penentuan Variabel Input dan Output}

Penelitian ini menggunakan tiga variabel input dan satu varibel output. Variabel inputnya terdiri dari:

\section{Nilai Investasi}

Nilai Investasi memiliki peran penting didalam suatu usaha untuk mengerakkan kehidupan ekonomi masyarakat, karena pembentukan modal akan memperbesar kapasitas produksi.

(Sukirno,2014) menyatakan investasi adalah pengeluaran penanaman modal yang dilakukan suatu perusahaan untuk membeli barangbarang modal dan perlengkapan-perlengkapan produksi untuk menambah kemampuan memproduksi barang-barang dan jasa-jasa yang tersedia dalam perekonomian. Dapat pula dikatakan bahwa investasi adalah pengeluaran yang ditujukan untuk menambah atau mempertahankan persediaan modal (capital stock). Persediaan modal ini terdiri dari pabrik, mesin-mesin, peralatan, persedian bahan baku yang dipakai dalam proses produksi. Yang termasuk dalam persediaan capital adalah rumah, dan persediaan barang yang belum terjual atau belum terpakai pada tahun yang bersangkutan. Jadi, investasi adalah pengeluaran yang menambah modal.

\section{Biaya Bahan Baku}

Biaya Bahan Baku merupakan biaya yang dikeluarkan untuk persedian Bahan Baku guna untuk menghasilkan jumlah produk yang semakin banyak. Menurut (Muktiadji, 2016) bahan baku merupakan faktor utama yang menunjang terhadap kelancaran proses produksi. Kelancaran proses produksi dengan dukungan pengendalian persediaan bahan baku yang memadai akan menghasilkan barang yang siap diolah pada waktu yang tepat dan sesuai dengan rencana produksi. Bahan baku merupakan bahan yang membentuk bagian besar produk jadi. Sedangkan menurut Suyadi Prawirosentono (2017) bahan baku adalah bahan utama dari suatu produk atau barang.

Tersedianya bahan baku maka diharapkan perusahaan industri dapat melakukan proses produksi sesuai permintaan konsumen. Selain itu dengan adanya persediaan menghindari terjadinya kekurangan bahan baku danketerlambatan jadwal pemenuhan produk. Menurut Sudarsono, bahan baku atau bahan mentah yang digunakan dalam proses produksi dikelompokkan menjadi dua, yaitu:

a) Bahan baku langsung adalah bahan mentah yang merupakan bagian dari barang jadi yang dihasilkan. Biaya yang dikeluarkan untuk membeli bahan baku ini mempunyai hubungan erat dan sebanding dengan jumlah barang jadi yangdihasilkan.

b) Bahan baku tidak langsung adalah bahan baku yang ikut berperan dalam proses produksi, tetapi tidak secara langsung tampak pada barang yang dihasilkan.

\section{Biaya TenagaKerja}

Menurut Simanora (2012), Biaya Tenaga Kerja adalah biaya yang dikeluarkan untuk pekerja atau karyawan yang dapat ditelusuri secara fisik kedalam pembuatan produk dan bisa pula ditelusuri dengan mudah atau tanpa biaya banyak. Biaya Tenaga Kerja diartikan sebagai 
suatu balas jasa yang diberikan sebagai pengganti tenaga kerja orang yang menjual tenaganya yang pada umumnya berupa uang atau sesuatu yang dapat dinilai dengan uang

Nitisemito (2012). Biaya Tenaga Kerja mempunyai peran penting dalam kegiatan usaha sebagai faktor produksi yang aktif dalam mengolah faktor-faktor produksi lainnya. Biaya Tenaga kerja perlu diperhitungkan dalam setiap proses produksi. Biaya tenaga kerja yang cukup tidak hanya dilihat dari tersedianya tenaga kerja tetapi juga dilihat dari kualitas serta jumlah tenaga kerja yangdigunakan.

\section{Nilai Produksi}

Didalam suatu industri, nilai dari barang yang diproduksi sangat berperan penting terutama dalam meningkatkan keuntungan atau laba. Nilai produksi adalah harga satuan atau harga dari keseluruhan jumlah barang yang dihasilkan oleh suatu perusahaan industri (Sumarsono,2013). Naik turunnya permintaan pasar hasil produksi akan berpengaruh apabila permintaan hasil produksi barang perusahaan meningkat, maka produsen cenderung untuk menambah kapasitas produksinya. Nilai output suatu daerah akan mengalami peningkatan produksi dengan bertambahnya jumlah perusahaan yang memproduksi barang dan jasa yang sejenis. Apabila jumlah output yang dihasilkan oleh perusahaan yang jumlahnya lebih besar maka akan menghasilkan output yang besar juga, sehingga semakin banyak jumlah perusahaan yang berdiri maka akan semakin banyak kemungkinan untuk terjadi penambahan output produksi.

\section{Metodologi Penelitian}

\section{Objek dan Lokasi Penelitian}

objek dalam penelitian ini adalah nilai investasi, biaya tenaga kerja, biaya bahan baku dan nilai produksi dari unit industri perabot di kecamatan Jeumpa Kabupaten Bireuen. Lokasi penelitian di Kecamatan Jeumpa Kabupaten Bireuen.

\section{Metode Analisis Data}

Dalam penelitian ini menggunakan jenis penelitian deskriptif. Untuk menganalisis efisiensi penggunaan modal usaha, tenaga kerja dan bahan baku oleh para pengrajin industri perabot Penelitian ini menggunakan Metode DEA (Data Envelopment Analysis) Yaitu suatu metode untuk mengevaluasi dan memecahkan masalah dengan cara mengintregrasikan beberapa masukan dan keluaran.

\section{Pengujian Efisiensi Menggunakan Pendekatan Variabel Return to Scale (VRS)}

Model ini beranggapan bahwa perusahaan tidak atau belum beroperasi pada skala yang optimal. Asumsi dari model ini adalah bahwa rasio antara penambahan input dan output tidak sama (Variable Return to Scale). Artinya, penambahan input sebesar $\mathrm{n}$ kali tidak akan menyebabkan output meningkat sebesar x kali, bisa lebih kecil atau lebih besar dari n kali. Peningkatan proporsi bisa bersifat Increasing Return to Scale (IRS) atau bisa juga bersifat Decreasing Return To Scale (DRS). Hasil modle ini menambahkan kondisi Convexity bagi nilai-nilai bobot $\lambda$, dengan memasukkan dalam model batasan berikut:

$$
\sum_{j=1}^{n} \lambda j=1
$$

Selanjutnya model BCC dapat ditulis dengan persamaan berikut: $\lambda$

Max $\pi$ (Efisiensi DMU Model VRS)

Subject to:

$\begin{array}{lll}\sum_{j=1}^{n} x i j & \mathrm{i}=1,2, \ldots, \mathrm{m} \\ \sum_{j=1}^{n} \text { yrj } & \lambda i j \geq \pi i o & \mathrm{r}=1,2, \ldots, \mathrm{s} \\ \sum_{j=1}^{n} \lambda j \geq 1 & \mathrm{j}=1,2, \ldots, \mathrm{n}\end{array}$

\section{Dimana:}

$$
\begin{array}{ll}
\pi & =\text { Efisiensi DMU Model VRS } \\
\mathrm{n} & =\text { Jumlah DMU } \\
\mathrm{m} & =\text { Jumlah Input } \\
\mathrm{s} & =\text { Jumlah Output } \\
\mathrm{xij} & =\text { Jumlah Input ke-i DMU j } \\
\mathrm{yrj} & =\text { Jumlah Output ke- } \mathrm{r} \text { DMU } j \\
\lambda \mathrm{j} & =\text { Bobot DMU j untuk DMU yang } \\
& \quad \text { dihitung. }
\end{array}
$$

\section{Hasil dan Pembahasan}

Terdapat tiga puluh (30) usaha industri perabot di Kecamatan Jeumpa Kabupaten Bireun yang memperoleh nilai skala efisien sama dengan satu (=1) yang berarti bahwa ketiga puluh usaha industri perabot tersebut telah mengefisienkan penggunaan input nilai investasi, biaya tenaga 
kerja dan biaya bahan baku untuk menghasilkan output nilai produksi.

Usaha industri perabot di Kecamatan Jeumpa Kabupaten Bireun yang telah mengefisiensikan penggunaan input nya tersebut guna menghasilkan output yang maksimal ialah usaha industri perabot milik Nasruddin M Hamzah, Fauzi M Daud, Asrul Helmi, Muzakkir, Usman Taleb, Malek Ridwan, M Yunus, Sanusi M Yunus, M Yusuf, Ridwan Harun, Muktaruddin, Tgk Safruddin, Sulaiman, Adam Usman, Anwar M Jamil, M Nasir A Latif, Zulkifli, Muhammad Idris, M Nur A Gani, Mawardi H Usman, H Sutyafar Ab, Muntasir Ibrahim, Syahrul Wardi Umar, Nasruddin, M Yusuf, Tarmizi Umar, Asmunir, Saiful M Saleh, Fajri Za, dan Syafruddin.

Terdapat dua puluh tiga (23) usaha industri perabot di Kecamatan Jeumpa Kabupaten Bireun yang memperoleh nilai skala efisiensi kurang dari satu $(<1)$ atau yang berarti belum mengefisienkan penggunaan input guna menghasilkan output yang maksimal ialah usaha industri perabot milik Fadli Muhammad, M Yusuf Ismail, Zamzami M Yusuf, Amiruddin, Mawardi, Mulyadi, Mustafa, M Nasir Ishak, Ridwan Muzakkir, Syambudiman, Zainuddin Ishak, Nurdin M Yusuf, A Bakar Arifin, Isa Ansari Daud, Syarifuddin, Zakaria Hamzah, Salahuddin, Mukti, Sofyan Ridwan, Ramli A Jalil, Zulfikar, Zulkifli Ismail, dan Syukri Saleh. Berikut disajikan contoh rekomendasi DEA untuk unit industry yang belum efisien dalam penggunaan input.

a. Contoh rekomendasi DEA untuk Industri Perabot milik Fadli Muhammad, M. Yusuf Ismail, dan Zamzami M Yusuf dapat dilihat pada tabel berikut

Tabel 1. Rekomendasi DEA

\begin{tabular}{|l|rrrrr|}
\hline Input Output & $\begin{array}{c}\text { Tingkat } \\
\text { Efisiensi }\end{array}$ & $\begin{array}{c}\text { Original } \\
\text { value }\end{array}$ & $\begin{array}{c}\text { Target } \\
\text { Value }\end{array}$ & $\begin{array}{c}\text { Radial } \\
\text { movement }\end{array}$ & $\begin{array}{c}\text { Slack } \\
\text { movement }\end{array}$ \\
\hline & 0,919 & & & & \\
\hline $\begin{array}{l}\text { Nilai Produksi } \\
\text { Rp) }\end{array}$ & 140.000 .000 & 140.000 .000 & 0.000 & 0.000 \\
\hline $\begin{array}{l}\text { Nilai Investasi } \\
\text { Rp) }\end{array}$ & 30.000 .000 & 27.568 .443 & -2.431 .557 & 0.000 \\
\hline $\begin{array}{l}\text { Tenaga Kerja } \\
\text { (Orang) }\end{array}$ & 3 & 2,554 & $-0,243$ & $-0,203$ \\
\hline $\begin{array}{l}\text { Nilai bahan } \\
\text { baku (Rp) }\end{array}$ & 70.000 .000 & 64.326 .366 & -5.673 .634 & 0.000 \\
\hline
\end{tabular}

Sumber : Hasil olah data, 2020

Berdasarkan tabel di atas diketahui inefisien efisiensi usaha industri perabot milik Fadli
Muhammad, M Yusuf Ismail, dan Zamzami M Yusuf sebesar 0,919.

Usaha industri perabot milik Fadli Muhammad M, Yusuf Ismail, dan Zamzami M Yusuf mengalami inefisiensi pada input nilai investasi dan nilai bahan baku. Input nilai investasi yang telah digunakan oleh usaha industri perabot milik Fadli Muhammad adalah sebesar Rp 30.000.000,- sedangkan nilai targetnya sebesar Rp 27.568.443 yang berarti bahwa untuk mengefisiensikan nilai investasi maka usaha industri perabot ini harus menurunkan investasinya sebesar Rp 2.431.557 atau sama dengan pengurangan nilai investasi sebesar $8.11 \%$ dengan dengan slack movement sebesar Rp 0 .

Pada input nilai bahan baku terlihat pada tabel bahwa industri perabot menggunakan nilai bahan baku Rp 70.000.000,- sedangkan berdasarkan perhitungan metode DEA pendekatan VRS orientasi input, usaha industri perabot ini harus menurunkan nilai bahan baku menjadi Rp 64.326.366,- atau pengurangan sebesar Rp 5.673.634,- guna mengefisienkan output nilai produksi yang telah dihasilkan.

b. Contoh rekomendasi DEA untuk Industri Perabot Milik Amiruddin, Mawardi, Mulyadi, Mustafa, M Nasir Ishak, Ridwan Muzakkir, Zainuddin Ishak, Nurdin M Yusuf, A Bakar Arifin, dan Isa Ansari Daud dapat dilihat pada tabel berikut

. Tabel 2. Rekomendasi DEA

\begin{tabular}{|l|rrrrr|}
\hline Input Output & $\begin{array}{c}\text { Tingkat } \\
\text { Efisiensi }\end{array}$ & $\begin{array}{c}\text { Original } \\
\text { value }\end{array}$ & $\begin{array}{c}\text { Target } \\
\text { Value }\end{array}$ & $\begin{array}{c}\text { Radial } \\
\text { movement }\end{array}$ & $\begin{array}{c}\text { Slack } \\
\text { movement }\end{array}$ \\
\hline & 0.952 & & & & \\
\hline $\begin{array}{l}\text { Nilai Produksi } \\
\text { Rp) }\end{array}$ & 150.000 .000 & 150.000 .000 & 0 & 0 \\
\hline $\begin{array}{l}\text { Nilai Investasi } \\
\text { (Rp) }\end{array}$ & 30.000 .000 & 28.548 .719 & -1.451 .281 & 0 \\
\hline $\begin{array}{l}\text { Tenaga Kerja } \\
\text { (Orang) }\end{array}$ & 3 & 2.650 & -0.145 & -0.205 \\
\hline $\begin{array}{l}\text { Nilai bahan } \\
\text { baku (Rp) }\end{array}$ & 70.000 .000 & 66.613 .679 & -3.386 .321 & 0 \\
\hline
\end{tabular}

Sumber : Hasil olah data, 2020

Berdasarkan tabel di atas diketahui nilai inefisien untuk efisiensi pemakaian input pada unit industry perabot Amiruddin, Mawardi, Mulyadi, Mustafa, M Nasir Ishak, Ridwan Muzakkir, Zainuddin Ishak, Nurdin M Yusuf, A Bakar Arifin, dan Isa Ansari Daud sebesar 0.952. Input yang mengalami inefisiensi atau nilai originalnya tidak sama dengan nilai targetnya adalah pada input nilai investasi dan nilai bahan baku. Pada

143 | Jurnal Ekonomi dan Manajemen Teknologi Vol. 4 | No. 2 | 2020 
input nilai investasi, agar terjadi efisiensi dibutuhkan pengurangan sebesar Rp 1.451.281,- sehingga menjadi Rp 28.548.719,Kemudian pada input nilai bahan baku unit usaha industri perabot tersebut juga harus menurunkan Rp 3.386.321,- menjadi Rp 66.613.679,--.

\section{Kesimpulan dan Saran}

Terdapat 30 (tiga puluh) unit usaha dari 53 (lima puluh tiga) unit usaha industri perabot di Kecamatan Jeumpa yang telah mengefisienkan penggunaan input tenaga kerja, nilai investasi dan nilai bahan baku untuk menghasilkan output nilai produksi yang maksimal, dan sisanya sebanyak dua puluh tiga (23) unit usaha industri perabot yang memperoleh nilai skala efisiensi kurang dari satu $(<1)$ atau yang berarti belum mengefisienkan penggunaan input guna menghasilkan output yang maksimal.

Kepada para pengusaha industri perabot khususnya pengusaha industri perabot di Kecamatan Jeumpa Kabupaten Bireuen diharapkan dalam menjalankan usahanya dapat mengkombinasikan penggunaan input sebaik mungkin sehingga mampu mengahsilkan output yang efisien dan memperoleh keuntungan maksimal. Teknik dan metode kombinasi yang tepat akan dapat diperoleh dengan cara menjalin kerjasama dan mengikuti rekomendasi dari para pakar ekonomi dan pemasaran. Kerjasama dengan pihak pemerintah dan swasta juga diperlukan agar diperoleh bantuan investasi moda usaha dan perluasan pangsa pasar.

Adapun saran dari penelitian ini, adanya dukungan pemerintah daerah juga sangat diperlukan untuk meningkatkan dan memajukan sector industri. Dukungan dapat berupa dukungan moril dan dukungan nyata seperti bantuan investasi, hibah dana, event yang merangsang kompetisi para pengusaha untuk menghasilkan produk yang berkualitas tinggi dan pelatihan-pelatihan untuk pengusaha dan tenaga kerja sector industri sehingga mampu meningkatkan hard skill dan soft skill mereka, selain itu dukungan promosi dan bantuan berupa perluasan pangsa pasar akan sangat membantu perkembangan usaha dan meningkatkan motivasi usaha masyarakat.

Dukungan dari masyarakat juga sangat diperlukan, membudayakan kembali pemikiran "membeli dari saudara sendiri' atau sikap 'lihat penjualnya dulu sebelum membeli" akan melahirkan rasa kepedulian, cinta tanah air dan rasa persaudaraan dan saling dukung diantara masyarakat, sehingga mampu menguatkan kembali sector industri kecil dan menengah di daerah dan pada akhirnya akan memperbaiki perekonomian negera.

\section{Daftar Pustaka}

Bilas, Richard A (2018), Teori Mikro Ekonomi.Erlangga: Jakarta.

Gujarati dan porter (2019), Dasar-dasar Ekonomitrika. Salemba Empat. Jakarta

Sugiyono (2019), Metode Penelitian Kuantitatif, Kualitatif, Bandung Alfabeta.

Simajuntak, Payaman J (2013), Produktivitas Kerja Pengertian dan Ruang Lingkupnya, Prisma. Jakarta.

Sumarsono, Sony (2013), Ekonomi Sumber Daya Manusia dan Ketenagakerjaan. Yogyakarta, Graha Ilmu.

IKomang Suartawan, I.B Purbadharmaja (2019), Pengaruh Modal dan Bahan Baku Terhadap Pendapatan Melalui Produksi Pengrajin Patumg Kayu di Kecamatan Sukasakti Kabupaten Gianyar. E-Jurnal Ekonomi Pembangunan Universitas Udayana. Vol. 6. No. 9.

Maryati, Riski (2015), Analisis Produksi Industri Funiture dan Kayu di Kota Pekanbaru. E-jurnal Fakultas Ekonomi Vol.2. No 2.

Putra, Eka, Riky (2012), Pengaruh Nilai Investasi Nilai Upah dan Nilai Produksi Terhadap Penyerapan Tenaga Kerja pada Industri Mebel di Kecamatan Ped Anonymous. (2012). Green Education Centre. http:// budidaya-sorgum.html Diakses tanggal 30 Juni 2012. 
Respikasari., T, Ekowati., dan A, Setiadi. (2014). Analisis Efisiensi Ekonomi Penggunaan Faktor-Faktor Produksi Usahatani Padi Sawah di Kabupaten Karanganyar. J. Agribisnis dan Agrowisata 5 (1) : 1-11.

Perdana, Adie, Herry, Gede (2017), Pengaruh Modal Tingkat Upah Penyerapan Tenaga Kerja Terhadap Produksi kerajinan Patung Padas Kecamatan Sukawati. Ejurnal Ekonomi Pembangunan Udayana.Vol.6. No 7.

Supriyanto (2015), Pengaruh Jumlah Tenaga Kerja dan Jumlah Modal Terhadap Pendapatan Home Industri Daur Ulang di Desa Seketi. Jurnal Trisuha LP2M Undar. Edisi 2 Vol. 2. 